\title{
Adaptability of Citrus Species Based on the Relationships between Climatic Parameters and Fruit Quality Characteristics ${ }^{1}$
}

\author{
Naoto Iwasaki and Chiaki Oogaki \\ Institute of Agriculture and Forestry, University of \\ Tsukuba, Sakura, Ibaraki 305 \\ Masao Iw Amasa \\ Faculty of Agriculture, Saga University, Honjyo, Saga 840 \\ Jiro Matsushima \\ Faculty of Agriculture, Mie University, Tsu 514 \\ Kiyotake Ishinata \\ Faculty of Agriculture, Kagoshima University, Kagoshima 890
}

\begin{abstract}
Summary
In the majority of middle and late maturing citrus species and cultivars, the relationships between climatic parameters including temperature, precipitation, sunshine and solar radiation, and morphological characteristics and inherent quality of the fruit, for which data were collected from many locations in Japanese citrus growing areas during several years, were analyzed by single and multiple regression analysis. The objective of the investigation was to determine the range of variations in temperature, precipitation, sunshine and solar radiation in the citrus growing areas where citrus fruits of distinctive quality are produced.

Temperature is the climatic factor which was found to have greatest effect on fruit quality characteristics, in particular the citric acid content, Brix/acidity ratio, juice $\mathrm{pH}$, rind thickness, flesh percentage, shape index of fruit and fruit weight. The parameters related to temperature included the annual mean temperature, mean temperature from Apr. to Nov. and annual effective cumulative temperature.

Rainfall was also found to significantly affect several fruit quality characteristics. Contradictoly results were obtained for relationships between the precipitation and the citric acid content in juice. These disagreements may be ascrived to the interaction of factors including the duration of rainfall, the rainfall intensity in each period and the development and maturation period of fruit.

The changes observed in the fruit quality characteristics related to the climatic parameters did not correspond to variations in the Brix values but corresponded to variations in the citric acid content and the Brix/acidity ratio.

Five multiple regressions among the fruit quality characteristics (Dependent variable) and the climatic parameters (Independent variable) were obrained. The climatic conditions associated with a high fruit quality in 8 citrus species and cultivars, based on the relationships obtained from the regression lines, were tabulated.

The relationships between mean monthly temperature, monthly duration of sunshine and monthly solar radiation were highly significant. In further investigations, the annual cumulative solar radiation should be determined to assess the adaptability of citrus species.
\end{abstract}

1 Received for publication August 14, 1985.

This work was supported in part by a Grant-Aid for Science Reseach (No. 56360003) from the Ministry of Education, Science and Culture, Japan. 


\section{Introduction}

In Japan, a lage number of middle and late maturing species and cultivars belonging to the genus Citrus have been extensively planted. Climatic problems associated with fruit quality tend to be more serious in some areas than in others. There is much evidence( 1 , $4,6,8,9)$ suggesting that the meteorological conditions in the citrus growing areas are the most important factors influencing fruit quality. As a result, variations in fruit quality due to climatic conditions are generally greater than the variations among orchard in the same area.

Data, covering climatic conditions and fruit quality of the major species and cultivars in Japan, were collected from many locations in the citrus growing areas over a number of years. The relationships between climatic parameters, including temperature, precipitation, sunshine and solar radiation, and morphological and inherent fruit quality, as reflected in the Brix values and citric acid content, were analyzed by single and multiple regression analyses. As a result, a range of variations in temperature, precipitation, sunshine and solar radiation in the growing areas where citrus fruits of distinctive quality are produced were identified.

Rootstock and cultural practices, soil and topographical conditions of citrus orcherds, etc. are factors that influence the morphology and inherent quality of the fruits produced in a citrus growing area.

In the citrus growing regions of Japan, analysis of the climatic conditions is considered to be a good method for determming the suitability of a citrus growing area where quality fruits of middle and late maturing species are cultivated.

Correlations and single and multiple regressions between the fruit quality characteristics and the meteorological variables were mathematically analyzed in 3 surveys.

\section{Materials and Methods}

1. 1979 survey

Medium size fruit of Hassaku (C. hassaku Hort. ex. Tanaka), Iyo and 'Miyauchi' Iyo

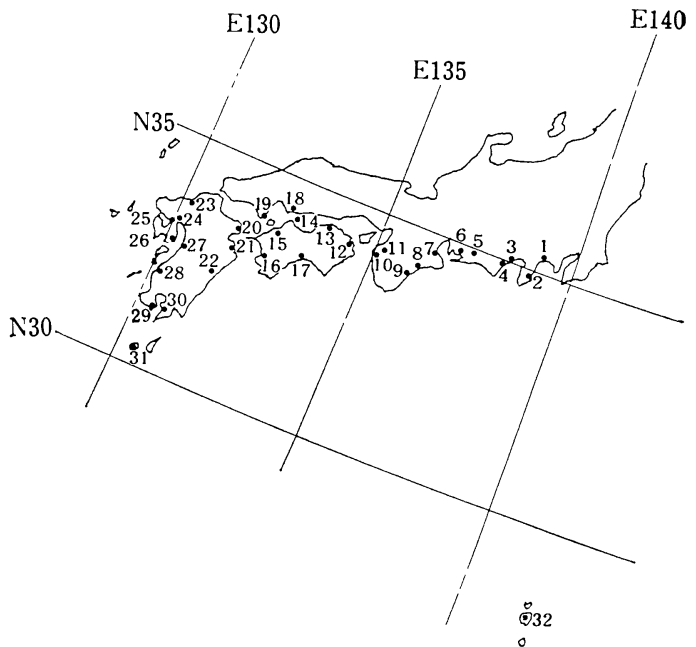

\begin{tabular}{|c|c|c|}
\hline Odawara(1)(2)(3) ${ }^{z}$ & 17. & Kohchi(2) \\
\hline Inatori $(1)(2)$ & 18. & Mihara(2) \\
\hline Okitsu(1)(2) & 19. & Ohshima(2) \\
\hline Shimizu(2) & 20. & Kunisaki(2) \\
\hline Mitsukabi (2) & 21. & Tsukumi(2) \\
\hline Gamagori(2) & 22. & Nango(2) \\
\hline $\mathrm{Tsu}(3)$ & 23. & Fukuoka(1)(2) \\
\hline Kumano(3) & 24. & Saga and Ogi(2)(3) \\
\hline Owase (2) (3) & 25. & Ohmura(2) \\
\hline $\operatorname{Arita}(1)(2)$ & 26. & Kuchinotsu(2) \\
\hline Kokawa(2) & 27. & Matsuhashi(2) \\
\hline Katsura (2) & 28. & Noda $(3)$ \\
\hline Sakaide(2) & 29. & Ibusuki(3) \\
\hline Iwaki(2) & 30. & Tarumizu(1)(2)(3) \\
\hline Matsuyama(1)(2) & 31. & Yaku-shima(2) \\
\hline Yoshida(2) & 32. & Ogasawara(2) \\
\hline
\end{tabular}

Fig. 1. Locations surveyed.

(1) Survey in 1979.

(2) Survey on the data published in 1974-79.

(3) Survey on the joint investigations from 1981 to 1983.

(C. iyo Hort. ex. Tanaka) and Ponkan ( $C$. reticulata Blanco) were harvested in late Dec. 1979 at the 6 Citrus Experiment Stations shown in Fig 1-(1) and were transported to the University of Tsukuba from Jan. to Feb. in the following year.

In Tsukuba, the morphological characteristics of the fruit, including specific gravity, rind color and thickness, flesh percentage and shape index of fruit, and juice quality, including $\mathrm{pH}$, specific gravity, Brix values and citric acid content were assessed.

Data on daily temperature, daily duration of sunshine and daily precipitation collected at the 6 stations from Apr. to Nov., 1979 were used and the annual duration of sunshine, mean temperature from Apr. to Nov., 
annual precipitation and annual effective cumulative temperature, were calculated.

Annual effective cumulative temperature calculated from following.

Annual effective cumulative temp.

$$
=\left(T_{\text {mean }} i-10^{\circ} \mathrm{C}\right) \mathrm{Ni}
$$

where

$$
\begin{aligned}
T_{\text {mean }} & =\text { Monthly mean temperature } \\
N & =\text { Number of days in a month } \\
i= & \text { Months with mean temperature } \\
& 10^{\circ} \mathrm{C}
\end{aligned}
$$

2. Analysis of the data published in the period 1974 1979

It was considered that if the values for the parameters relating to fruit quality characteristics in the published data were reviewed and the corresponding values for certain limited orchards as well as the data on harvesting time of each year were utilized, a better correlation coud be demonstrated between the fruit quality characteristics and the climatic parameters. In this survey, the data on fruit quality characteristics in the period 1974 1979 were analyzed 1) on the basis of the results published from 26 Citrus Experiment Stations as shown in Fig. 1-(2), 2) in limiting the data to standard cultured trees in long-term field experiments in each station, and 3) in limiting the studies on trees on trifoliate orange and fruits to with 2 months after optimum harvesting time.

The citrus species and cultivars which were surveyed were 'Washington', 'Morita', 'Suzuki' and 'Yoshida' navel orange, 'Fukuhara' orange (C. sinensis Osbek), Hassaku, 'Miyauchi' Iyo, 'Seminole' tangelo(C. paradisi $\times$ C. reticulata), 'Kara' mandarin $(C$. unshiu $\times$ C.noblis), Ponkan, Hyuganatsu ( $C$. tamurana Hort. ex. Tanaka) and 'Kawano' natsudaidai (C.natsudaidai Hayata).

The fruit quality characteristics(predictor variables) assessed included citric acid content, Brix values and Brix/acidity ratio, while the climatic parameters(criterion variables) consisted of the annual effective cumulative temperature, annual mean temperature, mean temperature from Apr. to Nov., from Apr. to May, from June to Aug. and Sept. to Nov., precipitation from Apr. to Nov. and the mean diurnal temperature range from Apr. to Nov., from Apr. to May, from June to Aug. and from Sept. to Nov. Because the criterion variables including missing values were omitted, degrees of freedom of each predictor variable were $7 \sim 9$.

3. Joint investigations at 4 locations from 1981 to 1983

Exchange of information of data collected during the surveys involved the following locations: Odawara, Mie (Kumano, Owase and Tsu), Saga and Kagoshima (Tarumizu, Noda and Ibusuki) which are shown in Fig. 1-(3). These locations corresponded to the north-eastern, central, south-western and southern part of the Pacific coast in Japan. Cultural practices and soil and topografical conditions of the orchards which were investigated in detail are not shown in this paper.

The climatic parameters and the fruit quality characteristics used are shown as $X_{1}-X_{11}$ and $Y_{1}-Y_{7}$ in Fig. 4. The duration of sunshine and the amount of solar radiation at each location were determined using a Jordan's sunshine recorder and a pyranometer or integrating pyranometer, respectively.

At each location, fruits of 'Miyagawawase' satsuma mandarin (C. unshiu Marc. var. praecox Tanaka) were harvested and analyzed in the middle of Oct., fruits of Hassaku, 'Miyauchi' Iyo and 'Morita' and 'Washington' navel oranges were harvested and analyzed in early Dec., and fruits of 'Marsh' and 'Duncan' grapefruits and 'Kawano' natsudaidai were harvested and analyzed in early Feb. For each species and cultivar, 15 20 medium sized fruits were sampled. The rind color was evaluated using a "Standerd color chart" which was prepared for orange color at the Fruit Tree Reserch Station. The citric acid titration in juice was performed using $0.1 \mathrm{~N}-\mathrm{NaOH}$ the specific gravity and the $\mathrm{pH}$ of juice were determined using a baume specific weight meter and glass-electrode $\mathrm{pH}$ meter respectevely and the Brix values in juice were determined using a digital refractometer.

\section{Results}

1. 1979 survey

Results of tests on the differences among 
Table 1. Effect of citrus production area on the fruit quality characteristics surveyed in 1979.

\begin{tabular}{|c|c|c|c|c|c|c|c|c|c|}
\hline & \multicolumn{4}{|c|}{ Fruit juice } & \multicolumn{5}{|c|}{ Fruit characterstics } \\
\hline & $\mathrm{pH}$ & $\begin{array}{l}\text { Specific } \\
\text { gravity }\end{array}$ & $\begin{array}{l}\text { Brix } \\
(\%)\end{array}$ & $\begin{array}{l}\text { Citric } \\
\text { acid } \\
(\%)\end{array}$ & $\begin{array}{l}\text { Shape } \\
\text { index }\end{array}$ & $\begin{array}{l}\text { Specific } \\
\text { gravity }\end{array}$ & $\begin{array}{l}\text { Rind } \\
\text { thickness } \\
\text { (mm) }\end{array}$ & $\begin{array}{l}\text { Flesh } \\
\text { percent. } \\
(\%)\end{array}$ & $\begin{array}{l}\text { Rind } \\
\text { color }\end{array}$ \\
\hline \multicolumn{10}{|c|}{ Hassaku } \\
\hline $\mathrm{TA}^{\mathrm{y}}$ & 3. $47 \mathrm{ab}^{\mathrm{z}}$ & $1.041 \mathrm{~d}$ & $9.2 \mathrm{~b}$ & $1.28 \mathrm{c}$ & 1. $26 \mathrm{ab}$ & $0.79 \mathrm{c}$ & $9.2 \mathrm{a}$ & 65 & $6.0 \mathrm{a}$ \\
\hline F U & $3.27 \mathrm{c}$ & 1. $042 \mathrm{~d}$ & 9. $8 \mathrm{bc}$ & $1.78 \mathrm{a}$ & 1. $21 \mathrm{bc}$ & $0.86 a$ & $6.6 \mathrm{~b}$ & 71 & $5.4 \mathrm{~b}$ \\
\hline MA & 3. $47 \mathrm{ab}$ & $1.048 \mathrm{a}$ & $10.7 \mathrm{a}$ & $1.37 \mathrm{bc}$ & 1. $20 \mathrm{c}$ & $0.83 b$ & $7.4 \mathrm{~b}$ & 62 & $6.0 \mathrm{a}$ \\
\hline A R I & $3.60 \mathrm{a}$ & $1.043 \mathrm{~cd}$ & $9.6 \mathrm{~cd}$ & $1.44 \mathrm{bc}$ & $1.21 \mathrm{dc}$ & $0.75 \mathrm{~d}$ & $9.2 \mathrm{a}$ & 59 & $6.0 \mathrm{a}$ \\
\hline OK I & 3. $38 \mathrm{bc}$ & $1.042 \mathrm{~d}$ & $9.2 \mathrm{~d}$ & 1. $38 \mathrm{bc}$ & $1.28 \mathrm{a}$ & $0.81 b c$ & $8.6 \mathrm{a}$ & 66 & $6.0 \mathrm{a}$ \\
\hline I NA & $3.37 \mathrm{bc}$ & $1.045 \mathrm{bc}$ & $9.7 \mathrm{ba}$ & $1.49 \mathrm{~b}$ & 1. $23 \mathrm{abc}$ & $0.80 c$ & $5.1 \mathrm{c}$ & 64 & $6.0 \mathrm{a}$ \\
\hline ODA & 3. $35 \mathrm{bc}$ & $1.046 \mathrm{bc}$ & $10.1 \mathrm{~b}$ & $1.51 \mathrm{~b}$ & 1. $26 \mathrm{ab}$ & $0.83 b$ & $7.7 \mathrm{~b}$ & 66 & $5.6 \mathrm{~b}$ \\
\hline $\mathrm{P}$ & 0.05 & 0.01 & 0.01 & 0.01 & 0.05 & 0.01 & 0.01 & ns & 0.05 \\
\hline \multicolumn{10}{|c|}{ Iyo } \\
\hline TA & $3.91 \mathrm{a}$ & $1.048 \mathrm{a}$ & $10.3 b$ & $1.36 \mathrm{c}$ & 1.17 & $0.80 \mathrm{a}$ & $5.2 \mathrm{e}$ & $69 a$ & $8.0 \mathrm{~b}$ \\
\hline F U & $3.27 \mathrm{c}$ & $1.043 \mathrm{~b}$ & $9.6 \mathrm{c}$ & $1.76 \mathrm{a}$ & 1.14 & $0.72 b c$ & $6.9 \mathrm{c}$ & $60 \mathrm{bc}$ & $8.0 \mathrm{~b}$ \\
\hline MA & 3. $74 \mathrm{ab}$ & $1.051 \mathrm{a}$ & $11.1 \mathrm{a}$ & 1.73ab & 1.13 & $0.67 \mathrm{c}$ & $7.8 \mathrm{~b}$ & $56 c$ & $10.0 \mathrm{a}$ \\
\hline OK I & $3.67 \mathrm{~b}$ & $1.049 \mathrm{a}$ & $11.0 \mathrm{a}$ & 1. $49 \mathrm{bc}$ & 1.18 & $0.77 \mathrm{a}$ & $6.3 \mathrm{~d}$ & $65 \mathrm{ab}$ & $9.8 \mathrm{a}$ \\
\hline I NA & $3.59 \mathrm{~b}$ & $1.050 \mathrm{a}$ & $10.9 \mathrm{ab}$ & 1. $67 \mathrm{ab}$ & 1. 20 & $0.76 \mathrm{ab}$ & $8.1 \mathrm{a}$ & $60 \mathrm{bc}$ & 7. $4 \mathrm{~b}$ \\
\hline $\mathrm{P}$ & 0.01 & 0.01 & 0.01 & 0.01 & $\mathrm{~ns}$ & 0.01 & 0.01 & 0.01 & 0.01 \\
\hline \multicolumn{10}{|c|}{ 'Miyauchi' Iyo } \\
\hline MA & $3.68 \mathrm{~b}$ & $1.048 \mathrm{~b}$ & $10.6 \mathrm{~b}$ & 1.44 & $1.37 \mathrm{a}$ & $0.72 \mathrm{c}$ & $6.5 \mathrm{ab}$ & $67 c$ & 9.2 \\
\hline A R I & $3.51 \mathrm{~d}$ & 1. 053a & $11.8 \mathrm{a}$ & 1.24 & $1.22 \mathrm{c}$ & $0.69 c$ & 6.1abc & $66 \mathrm{~b}$ & 9.0 \\
\hline OK I & $3.91 \mathrm{a}$ & $1.049 \mathrm{~b}$ & $10.6 \mathrm{~b}$ & 1.19 & $1.12 \mathrm{~d}$ & $0.77 \mathrm{~b}$ & $6.8 \mathrm{a}$ & $66 \mathrm{~d}$ & 9.6 \\
\hline I NA & 3. $67 \mathrm{~b}$ & $1.049 \mathrm{~b}$ & $10.6 \mathrm{~b}$ & 1. 18 & $1.28 \mathrm{~b}$ & $0.78 \mathrm{~b}$ & $5.1 \mathrm{bc}$ & $72 b$ & 9.2 \\
\hline ODA & $3.57 \mathrm{~b}$ & $1.048 \mathrm{~b}$ & $10.1 \mathrm{~b}$ & 1.26 & $1.27 \mathrm{~b}$ & $0.84 \mathrm{a}$ & $4.7 \mathrm{c}$ & $75 \mathrm{a}$ & 10.2 \\
\hline $\mathrm{P}$ & 0.01 & 0.01 & 0.01 & $\mathrm{~ns}$ & 0.01 & 0.01 & 0.01 & 0.01 & $\mathrm{~ns}$ \\
\hline \multicolumn{10}{|c|}{ Ponkan } \\
\hline MA & $3.91 \mathrm{~b}$ & $1.049 b$ & $11.3 \mathrm{~b}$ & $1.29 \mathrm{a}$ & $1.19 \mathrm{~b}$ & $0.82 \mathrm{~b}$ & 3. $7 \mathrm{a}$ & $69 \mathrm{bc}$ & $9.0 \mathrm{a}$ \\
\hline A R I & 4. $07 \mathrm{ab}$ & 1. $053 \mathrm{a}$ & 12. $8 \mathrm{a}$ & $0.98 \mathrm{ab}$ & $1.12 \mathrm{~b}$ & $0.72 b$ & 4. $4 \mathrm{a}$ & $67 \mathrm{c}$ & $8.8 \mathrm{a}$ \\
\hline OK I & 3. $93 \mathrm{~b}$ & $1.047 \mathrm{bc}$ & $10.7 \mathrm{bc}$ & $0.79 b c$ & $1.32 \mathrm{a}$ & $0.78 \mathrm{a}$ & 4. $1 \mathrm{ab}$ & $69 \mathrm{bc}$ & $7.4 \mathrm{~b}$ \\
\hline I NA & $4.54 \mathrm{a}$ & $1.043 \mathrm{~d}$ & $10.0 \mathrm{~d}$ & $0.48 \mathrm{c}$ & 1. $15 \mathrm{~b}$ & $0.82 \mathrm{a}$ & 3. $6 \mathrm{~b}$ & $73 a b$ & 7. $8 \mathrm{ab}$ \\
\hline ODA & $4.57 \mathrm{a}$ & $1.045 \mathrm{~cd}$ & 10. $3 \mathrm{cb}$ & $0.54 \mathrm{c}$ & $1.34 \mathrm{a}$ & $0.83 a$ & 3. $6 \mathrm{~b}$ & $77 \mathrm{a}$ & 8. $6 a b$ \\
\hline $\mathrm{P}$ & 0.05 & 0.01 & 0.01 & 0.01 & 0.01 & 0.01 & 0.05 & 0.01 & 0.05 \\
\hline
\end{tabular}

$z$ Different letters within a column represnt significant differences according to Duncan's multiple range test $(\mathrm{P}<0.01$ or $<0.05)$.

y TA; Tarumizu, FU ; Fukuoka, MA ; Matsuyama, ARI ; Arita, OKI ; Okitsu, INA ; Inatori, ODA ; Odawara.

mean values of fruit quality characteristics are presented in Table 1 . Correlations between fruit quality characteristics showing significant differences at $\mathrm{P}<0.05$ or $\mathrm{P}<0.01$ among the 7 locations listed in Table 1 and the climatic parameters in the respective locations were calculated the combinations showing significant correlations also being determined by regression. The results are shown in Fig. 2. A large number of significant differences in the values of fruit quality characteristics were detected at each location as the size of the fruits collected was not uniform. The combinations with highly significant correlations and their regression equations are shown in Fig. 2.

It can be seen that in Hassaku the citric acid content in juice was negatively correlated with the effective cumulative temperature. In Iyo higher effective cumulative temperature and mean temperature from Apr. to Nov. resulted in the production of fruits with a lower citric acid content, higher juice $\mathrm{pH}$, thinner rind and higher flesh percentage. In 'Miyauchi' Iyo the shape index of the fruit as represented by the width/ length ratio was positively correlated with the duration of sunshine from Apr. to Nov., while in Ponkan the citric acid content in juice was negatively correlated with the pre- 

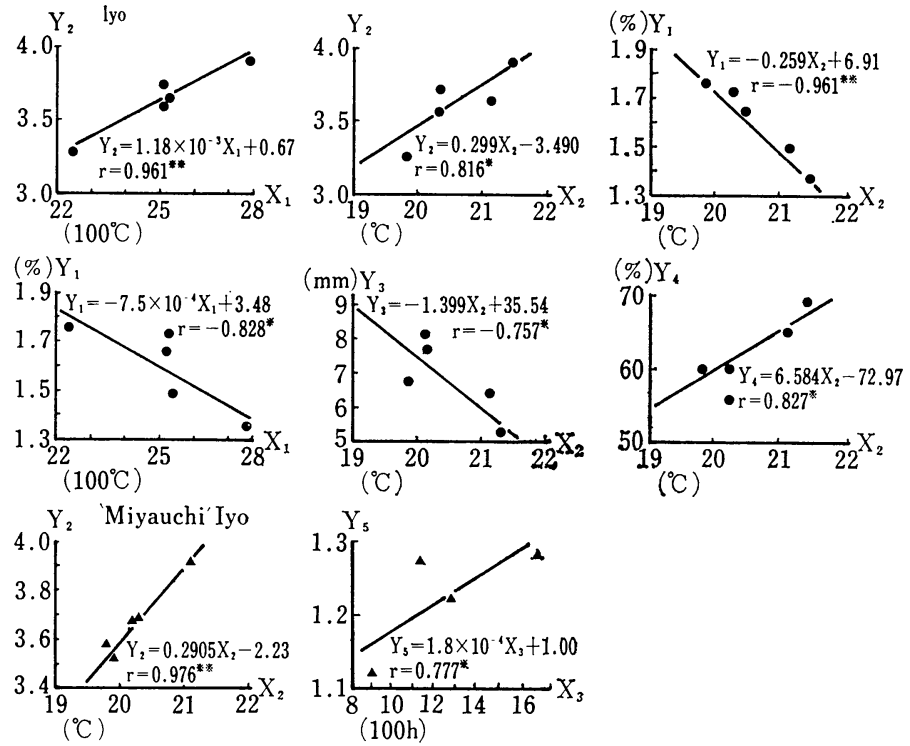

$\left({ }^{\circ} \mathrm{C}\right)$
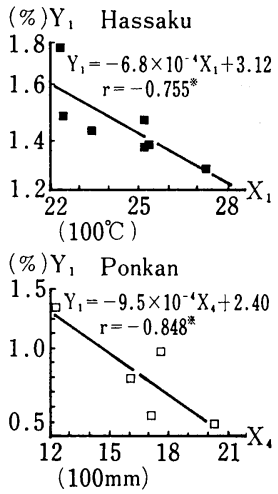

Fig. 2. Regression lines showing the relationships between the fruit quality chardicteristics of late maturing citrus species and the climatic parameters in 1979.

$Y_{1} ;$ Citric acid $(\mathrm{g} / 100 \mathrm{~g})$

$Y_{2} ;$ Juice $\mathrm{pH}$

$Y_{3} ;$ Rind thickness $(\mathrm{mm})$

$Y_{4} ;$ Flesh percentage $(\%)$

$Y_{5}$; Shape index of fruit (width/length)

$X_{1}$; Annual effective cumulative temp. $\left({ }^{\circ} \mathrm{C}\right)$

$X_{2}$; Mean temperature from Apr. to Nov. $\left({ }^{\circ} \mathrm{C}\right)$

$X_{3}$; Duration of sunshine from Apr. to Nov. (h)

$X_{4}$; Precipitation from Apr. to Nov. (mm)

cipitation from Apr. to Nov.

Neither the specific gravity and Brix values of juice as indices of the soluble solid content nor the specific gravity and flesh percentage of fruit were correlated with the climatic parameters.

2. Survey using the data published in the period 1974 1979

In Hyuganatsu 'Kara' mandarin, 'Kawano' natsudaidai and 'Fukuhara' orange, the results showed negative correlations between the fruit quality characteristics and the climatic parameters owing to the small number of locations and years investigated.

Combinations showing highly significant correlations and their regression equations by year and shown in Fig. 3. In Hassaku the citric acid content in juice was negatively cor- 

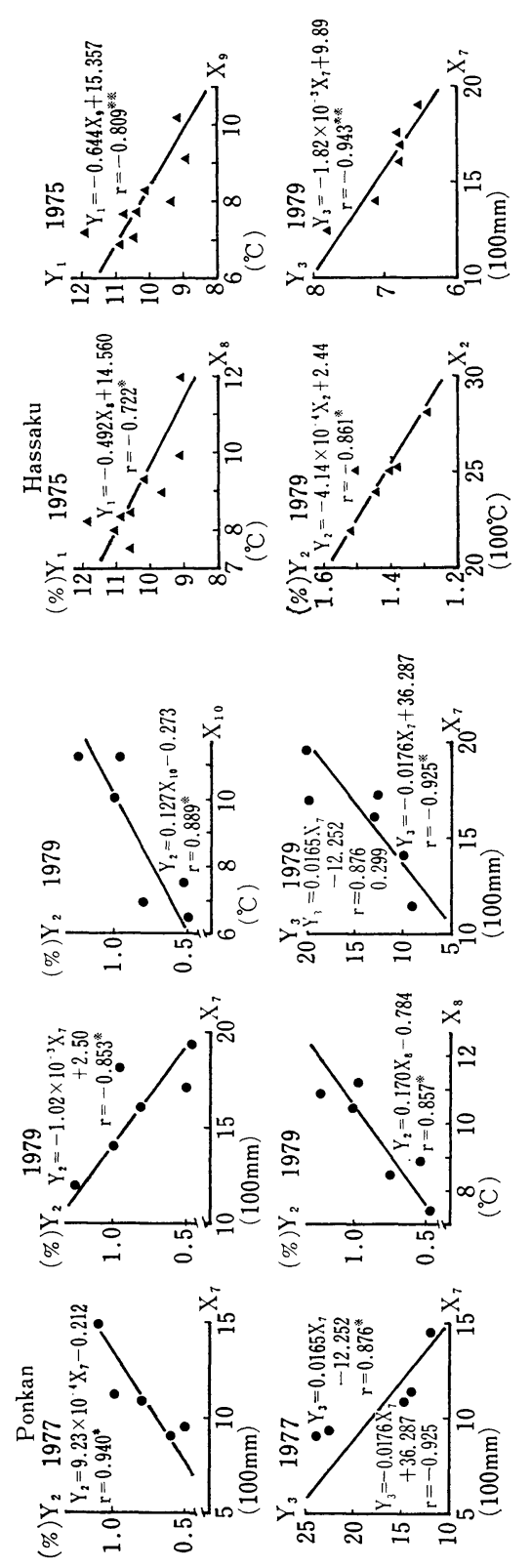
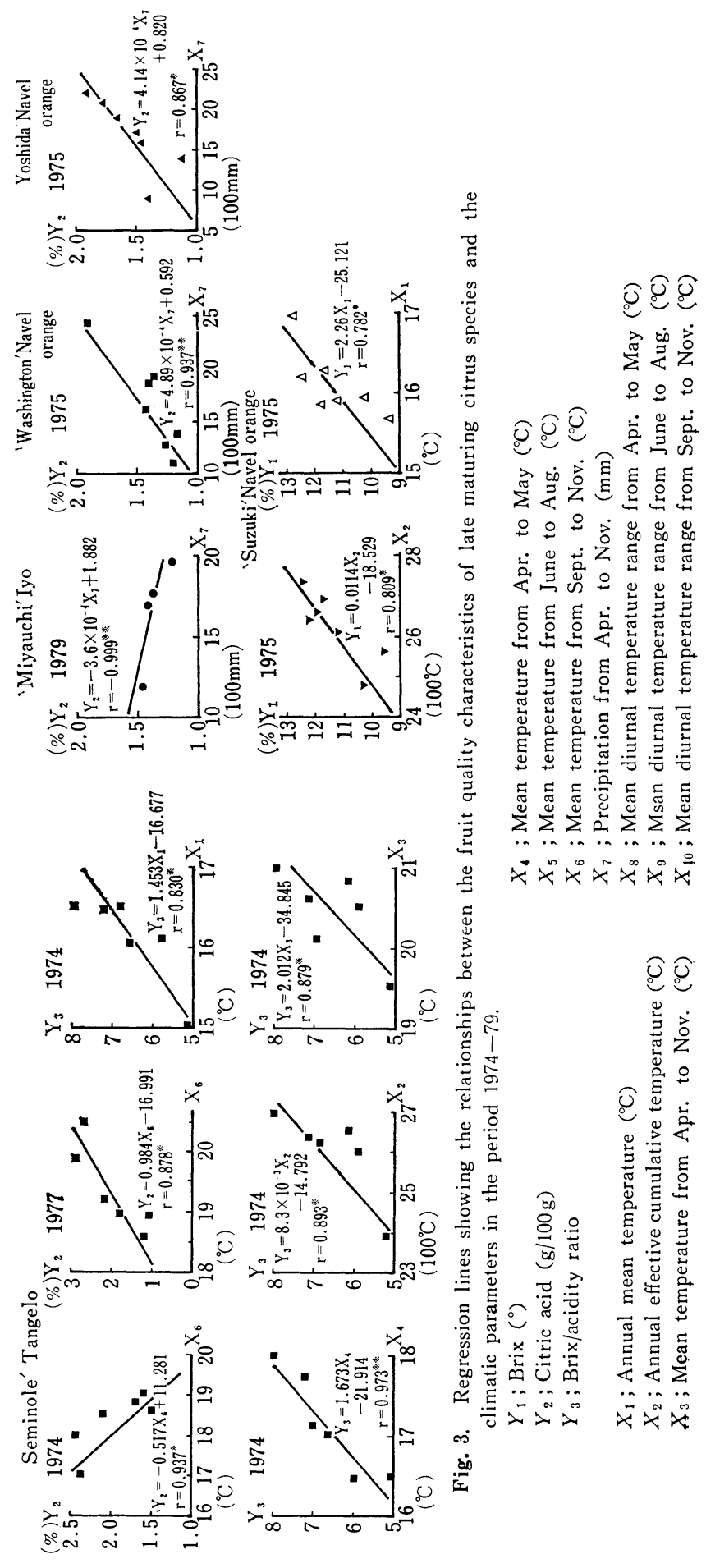

बิ워웡

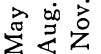

우 ᄂ

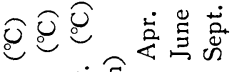

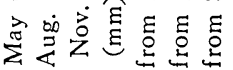

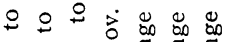

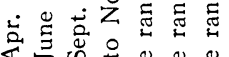

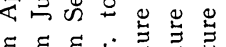
ह 톤

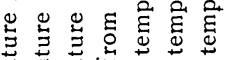
呵

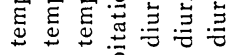

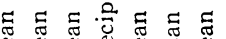
$\sum \Sigma \Sigma \Sigma \Sigma \Sigma \Sigma$ 엉 高 $+$ $2 \frac{a}{4}$ 혼 ह $\stackrel{\square}{\Xi}$ 焉 竞要 

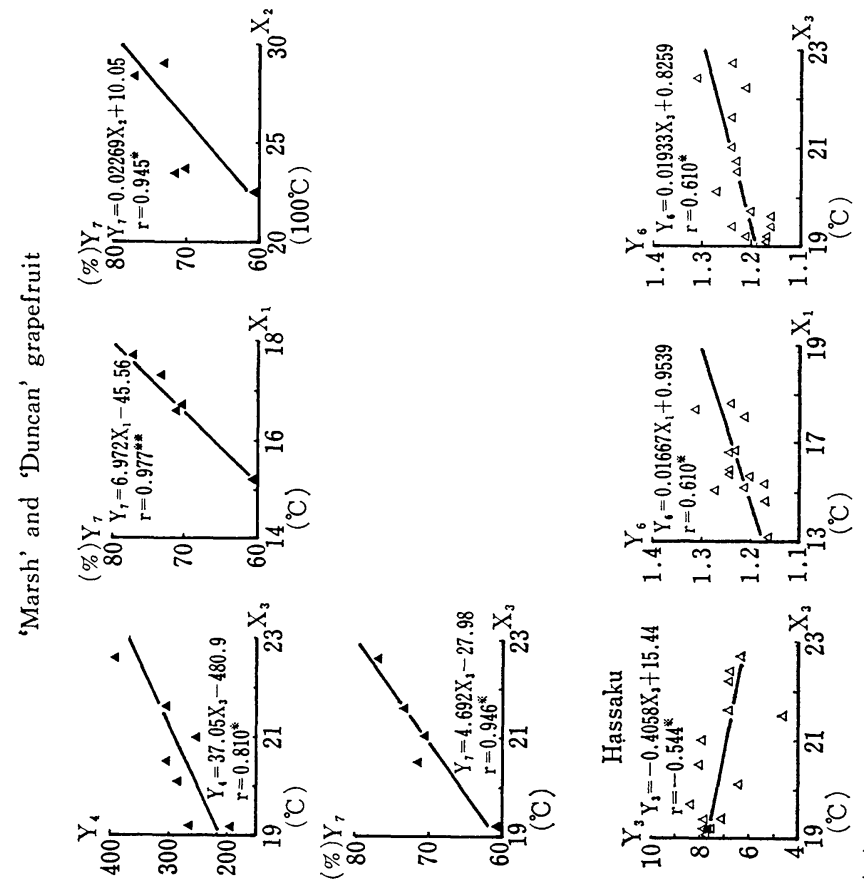

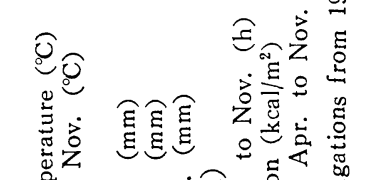

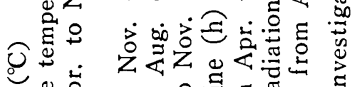

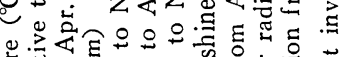

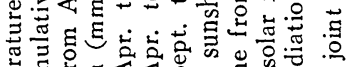

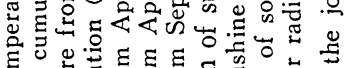

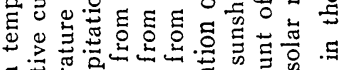

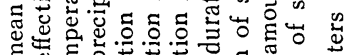

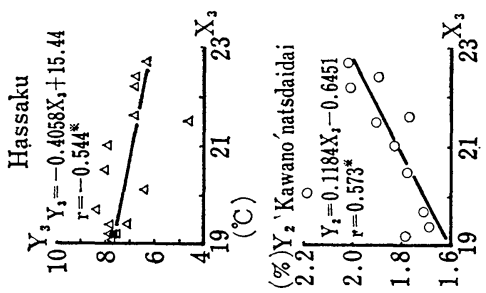

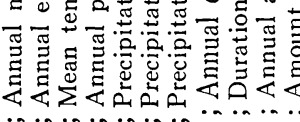

$\ddot{x} \ddot{x} \ddot{x} \ddot{x} \ddot{x} \ddot{x} \dot{x} \dot{x}=$
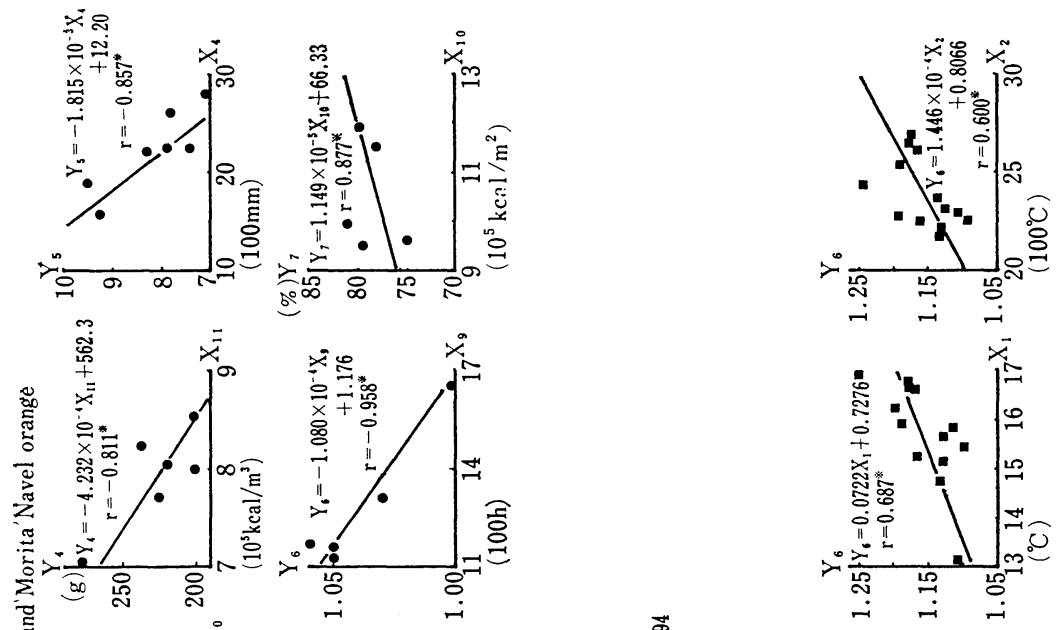

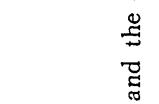
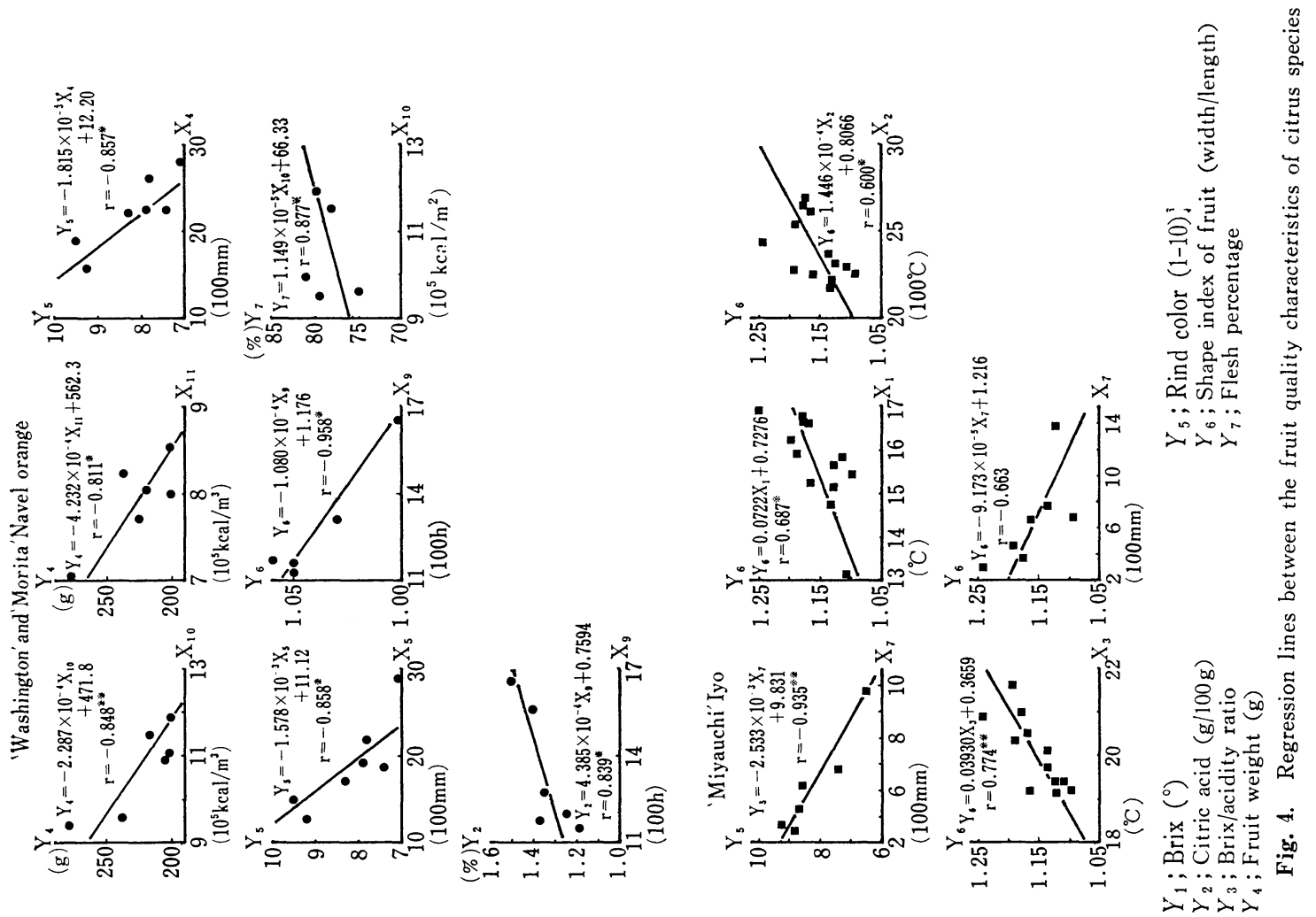
related with the annual effective temperature. In 'Seminole'tangelo it was negatively correlated in 1874 and positively correlated in 1977 with the mean temperature from Apr. to Nov. In 1977 the citric acid content in juice was negatively correlated in Iyo 'Miyauchi' Iyo and Ponkan and positively correlated in 'Washington' and 'Yoshida' navel oranges and Ponkan with the precipitation from Apr. to Nov. The relationships between the citric acid content in juice and precipitation from Apr. to Nov. varied according to the monthly precipitation during this period.

The Brix values in juice showed no significant correlation with climatic parameters. However, a positive correlation was observed between the Brix values in 'Suzuki' navel orange and both annual effective temperature and annual mean temperature. There was a negative correlation between the Brix values in Hassaku fruit and the mean diurnal temperature range from Apr. to Nov. and from June to Aug.

In 'Seminole' tangelo the Brix/acidity ratio in juice was positively correlated with the annual effective cumulative temperature, annual mean temperature and mean temperature from Apr. to Nov. and Apr. to May. In Ponkan it was negatively correlated in 1977 and positively correlated in 1979 with the precipitation from Apr. to Nov., and in Hassaku it was negatively correlated with the precipitation from Apr. to Nov.

A dependent variable, such as the citric acid content in juice, showed high correlation coefficients and regressions with various climatic parameters(independent variables), but a multiple regression with the climatic parameters could not be fitted.

3. Joint investigations and exchange of data and information at 4 locations

At every location, the methods of determining the quality characteristics of fruits and the studies on the climatic parameters used in the survey were as unifrom as possible and were continued over a period of 3 years. The combinations which showed significant coefficients of correlation between the fruit quality characteristics and the climatic parameters and their single regressions are shown in Table 2 along with the signifficant combinations at $\mathrm{P}<0.10$.

In 'Miyagawa-wase' satsuma mandarin and 'Kawano' natsudaidai, the fruit quality characteristics showed no significant correlations with the climatic parameters. However, in 'Kawano' natsudaidai, a positive correlation was found between the citric acid content in juice and mean temperature from Apr. to Nov.

In Hassaku, the Brix/acidity ratio in juice was negatively correlated with the mean temperature from Apr. to Nov. The shape index of 'Miyauchi' Iyo fruit showed significant correlations with several climatic parameters, in particular, there was a positive correlation with factors related to the temperature and negative correlation with the precipitation from Sept. to Nov. The rind color of the fruit showed a negative correlation significant at $\mathrm{P}<0.01$ with the precipitation from Sept. to Nov., indicating that the rich orange-red color became more pronounced due to the light rainfall during the ripening period of the fruit.

In grapefruit, the citric acid content in juice, the fruit weight and the flesh percentage showed high correlations with the factors related to temperature. The citric acid content in juice decreased while the fruit weight and flesh percentage increased with an increase in the cumulative temperature.

The fruit quality characteristics of navel orange were significantly correlated with the various climatic parameters. Of the $77 \mathrm{com}$ binations, 26 were significant at $\mathrm{P}<0.10,7$ were significant at $\mathrm{P}<0.05$ and 1 was significant at $\mathrm{P}<0.01$. The constituents of juice were not significantly correlated with the climatic parameters, except citric acid content which was positively correlated with the duration of sunshine from Apr. to Nov. With regard to the physical characteristics of fruit, there were negative correlations between the fruit weight and amount of solar radiation, between the rind color and the factors related to precipitation and between the shape index of fruit and the duration of sunshine.

In this survey there was no high correla- 
Table 2. Relationships between the fruit quality characteristics of citrus species and cultivars and the climatic parameters in the joint investigation from 1981 to 1983.

\begin{tabular}{|c|c|c|c|c|}
\hline \multicolumn{5}{|c|}{ Combination of highly signiffcant correlations } \\
\hline $\begin{array}{l}\text { Dependent } \\
\text { variable }\end{array}$ & $\begin{array}{l}\text { Independent } \\
\text { variable }\end{array}$ & $\begin{array}{l}\text { Correlation } \\
\text { coefficient } \\
(\mathrm{r})\end{array}$ & $\mathrm{P}$ & $\begin{array}{l}\text { Regression } \\
\text { equation }\end{array}$ \\
\hline \multicolumn{5}{|c|}{ 'Miyagawa-wase' satsuma mandarin $\cdots$ in 77 combinations } \\
\hline$Y_{1}^{z}$ & $X_{6}{ }^{\mathrm{y}}$ & -0.558 & 0.10 & \\
\hline$Y_{1}$ & $X_{11}$ & 0.662 & 0.10 & \\
\hline$Y_{2}$ & $X_{6}$ & 0.578 & 0.10 & \\
\hline$Y_{3}$ & $X_{6}$ & -0.560 & 0.10 & \\
\hline \multicolumn{5}{|c|}{ Hassaku $\cdots$ in 77 combinations } \\
\hline$Y_{1}$ & $X_{1}$ & -0.468 & 0.10 & \\
\hline$Y_{3}$ & $X_{3}$ & $-0.544^{*}$ & 0.05 & $Y_{3}=15.44-0.4058 X_{3}$ \\
\hline$Y_{4}$ & $X_{2}$ & 0.474 & 0.10 & \\
\hline$Y_{4}$ & $X_{6}$ & -0.619 & 0.10 & \\
\hline$Y_{4}$ & $X_{9}$ & 0.597 & 0.10 & \\
\hline$Y_{4}$ & $X_{11}$ & 0.669 & 0.10 & \\
\hline$Y_{5}$ & $X_{9}$ & -0.701 & 0.10 & \\
\hline$Y_{6}$ & $X_{1}$ & $0.620^{*}$ & 0.05 & $Y_{6}=0.9539+0.01667 X_{1}$ \\
\hline$Y_{6}$ & $X_{2}$ & 0.524 & 0.10 & \\
\hline$Y_{6}$ & $X_{3}$ & $0.610^{*}$ & 0.05 & $Y_{6}=0.8259+0.01933 X_{3}$ \\
\hline \multicolumn{5}{|c|}{ 'Miyauchi' Iyo $\cdots$ in 74 combinations } \\
\hline$Y_{2}$ & $X_{10}$ & -0.661 & 0.10 & \\
\hline$Y_{4}$ & $X_{2}$ & 0.483 & 0.10 & \\
\hline$Y_{4}$ & $X_{3}$ & 0.474 & 0.10 & \\
\hline$Y_{5}$ & $X_{4}$ & -0.649 & 0.10 & \\
\hline$Y_{5}$ & $X_{5}$ & -0.792 & 0.10 & \\
\hline$Y_{5}$ & $X_{7}$ & $-0.935^{* *}$ & 0.01 & $Y_{5}=9.831-2.533 \times 10^{-3} X_{7}$ \\
\hline$Y_{6}$ & $X_{1}$ & $0.687^{*}$ & 0.05 & $Y_{6}=0.7276+0.02722 X_{1}$ \\
\hline$Y_{6}$ & $X_{2}$ & $0.600^{*}$ & 0.05 & $Y_{6}=0.8066+1.446 \times 10^{-4} X_{2}$ \\
\hline$Y_{6}$ & $X_{3}$ & $0.774^{* *}$ & 0.01 & $Y_{6}=0.3659+0.03930 X_{3}$ \\
\hline$Y_{6}$ & $X_{7}$ & $-0.663^{*}$ & 0.05 & $Y_{6}=1.216-9.173 \times 10^{-5} X_{7}$ \\
\hline$Y_{6}$ & $X_{9}$ & -0.654 & 0.10 & \\
\hline$Y_{6}$ & $X_{10}$ & 0.649 & 0.10 & \\
\hline \multicolumn{5}{|c|}{ 'Washington and 'Morita' navel orange $\cdots$ in 77 combinations } \\
\hline$Y_{2}$ & $X_{8}$ & 0.795 & 0.10 & \\
\hline$Y_{2}$ & $X_{9}$ & $0.839 *$ & 0.05 & $Y_{2}=0.7594+4.385 \times 10^{-4} X_{9}$ \\
\hline$Y_{2}$ & $X_{10}$ & -0.646 & 0.10 & \\
\hline$Y_{3}$ & $X_{4}$ & 0.609 & 0.10 & \\
\hline$Y_{3}$ & $X_{5}$ & 0.569 & 0.10 & \\
\hline$Y_{3}$ & $X_{6}$ & 0.591 & 0.10 & \\
\hline$Y_{3}$ & $X_{8}$ & -0.671 & 0.10 & \\
\hline$Y_{3}$ & $X_{9}$ & -0.795 & 0.10 & \\
\hline$Y_{3}$ & $X_{10}$ & 0.675 & 0.10 & \\
\hline$Y_{4}$ & $X_{8}$ & 0.648 & 0.10 & \\
\hline$Y_{4}$ & $X_{9}$ & 0.685 & 0.10 & \\
\hline$Y_{4}$ & $X_{10}$ & $-0.848^{*}$ & 0.05 & $Y_{4}=471.8-2.287 \times 10^{-4} \mathrm{X}_{10}$ \\
\hline$Y_{4}$ & $X_{11}$ & $-0.811^{*}$ & 0.05 & $Y_{4}=562.3-4.232 \times 10^{-4} X_{11}$ \\
\hline$Y_{5}$ & $X_{4}$ & $-0.857^{*}$ & 0.05 & $Y_{5}=12.20-1.815 \times 10^{-3} X_{4}$ \\
\hline$Y_{5}$ & $X_{5}$ & $-0.858^{*}$ & 0.05 & $Y_{5}=11.12-1.578 \times 10^{-3} X_{5}$ \\
\hline$Y_{5}$ & $X_{6}$ & -0.698 & 0.10 & \\
\hline$Y_{5}$ & $X_{7}$ & -0.748 & 0.10 & \\
\hline$Y_{6}$ & $X_{1}$ & 0.541 & 0.10 & \\
\hline$Y_{6}$ & $X_{9}$ & $-0.958^{*}$ & 0.05 & $Y_{6}=1.176-1.080 \times 10^{-4} X_{9}$ \\
\hline
\end{tabular}


(Table 2. Continued from former page)

\begin{tabular}{|c|c|c|c|c|}
\hline \multicolumn{5}{|c|}{ Combination of highly significant correlations } \\
\hline $\begin{array}{l}\text { Dependent } \\
\text { variable }\end{array}$ & $\begin{array}{l}\text { Independent } \\
\text { variable }\end{array}$ & $\begin{array}{l}\text { Correlation } \\
\text { coefficient } \\
(\mathrm{r})\end{array}$ & $\mathrm{P}$ & $\begin{array}{l}\text { Regression } \\
\text { equation }\end{array}$ \\
\hline$Y_{6}$ & $X_{10}$ & 0.848 & 0.10 & \\
\hline$Y_{7}$ & $X_{1}$ & -0.463 & 0.10 & \\
\hline$Y_{7}$ & $X_{3}$ & -0.540 & 0.10 & \\
\hline$Y_{7}$ & $X_{4}$ & 0.735 & 0.10 & \\
\hline$Y_{7}$ & $X_{5}$ & 0.673 & 0.10 & \\
\hline$Y_{7}$ & $X_{10}$ & $0.877^{*}$ & 0.05 & $Y_{7}=66.33+1.149 \times 10^{-5} X_{13}$ \\
\hline$Y_{7}$ & $X_{11}$ & 0.669 & 0.10 & \\
\hline \multicolumn{5}{|c|}{ 'Marsh' and 'Duncan' grapefruit $\cdots$ in 48 combinations } \\
\hline$Y_{1}$ & $X_{5}$ & 0.650 & 0.10 & \\
\hline$Y_{1}$ & $X_{6}$ & 0.820 & 0.10 & \\
\hline$Y_{2}$ & $X_{1}$ & -0.669 & 0.10 & \\
\hline$Y_{2}$ & $X_{2}$ & -0.729 & 0.10 & \\
\hline$Y_{2}$ & $X_{3}$ & 0.596 & 0.10 & \\
\hline$Y_{2}$ & $X_{7}$ & 0.771 & 0.10 & \\
\hline$Y_{4}$ & $X_{1}$ & 0.682 & 0.10 & \\
\hline$Y_{4}$ & $X_{2}$ & 0.636 & 0.10 & \\
\hline$Y_{4}$ & $X_{3}$ & $0.810^{*}$ & 0.05 & $Y_{4}=-480.9+37.05 X_{3}$ \\
\hline$Y_{4}$ & $X_{5}$ & -0.836 & 0.10 & \\
\hline$Y_{6}$ & $X_{5}$ & -0.761 & 0.10 & \\
\hline$Y_{7}$ & $X_{1}$ & $0.977^{* *}$ & 0.01 & $Y_{7}=-45.56+6.972 X_{1}$ \\
\hline$Y_{7}$ & $X_{2}$ & $0.945^{*}$ & 0.05 & $Y_{7}=10.05+0.02269 X_{2}$ \\
\hline$Y_{7}$ & $X_{3}$ & $0.946^{*}$ & 0.05 & $Y_{7}=-27.98+4.692 X_{3}$ \\
\hline \multicolumn{5}{|c|}{ ‘Kawano' natsudaidai $\cdots$ in 74 combinations } \\
\hline$Y_{1}$ & $X_{1}$ & -0.482 & 0.10 & \\
\hline$Y_{1}$ & $X_{9}$ & -0.706 & 0.10 & \\
\hline$Y_{2}$ & $X_{3}$ & $0.573^{*}$ & 0.05 & $Y_{2}=-0.6451+0.1184 X_{3}$ \\
\hline$Y_{3}$ & $X_{3}$ & -0.539 & 0.10 & \\
\hline$Y_{6}$ & $X_{6}$ & -0.731 & 0.10 & \\
\hline$Y_{7}$ & $X_{10}$ & 0.746 & 0.10 & \\
\hline
\end{tabular}

$z \quad Y_{1} ; \operatorname{Brix}\left({ }^{\circ}\right)$

$Y_{2} ;$ Citric acid $(\% 100 \mathrm{~g})$

$Y_{3} ;$ Brix/acidity ratio

$Y_{4}$; Fruit weight $(\mathrm{g})$

$Y_{5} ;$ Rind color (1-10)

$Y_{6} ;$ Shape index of fruit (width/length)

$Y_{7} ;$ Flesh percentage (\%)

y $X_{1}$; Annual mean temperature $\left({ }^{\circ} \mathrm{C}\right)$

$X_{2}$; Annual effective cumulative temperature $\left({ }^{\circ} \mathrm{C}\right)$

$X_{3}$; Mean temperature from Apr. to Nov. $\left({ }^{\circ} \mathrm{C}\right)$

$X_{4}$; Annual precipitation ( $\mathrm{mm}$ )

$X_{5}$; Precipitation from Apr. to Nov. (mm)

$X_{6}$; Precipitation from Apr. to Aug. (mm)

$X_{7}$; Precipitation from Sept. to Nov. (mm)

$X_{8} ;$ Annual duration of sunshine (h)

$X_{9}$; Duration of sunshine from Apr. to Nov. (h)

$X_{10}$; Annual amount of solar radiation $\left(\mathrm{kcal} / \mathrm{m}^{2}\right)$

$X_{11}$; Amount of solar radiation from Apr. to Nov. (kcal/ $\mathrm{m}^{2}$ )

tion coefficient with the Brix values in juice of any species or cultivar.

For the combinations showing a significant correlation over $\mathrm{P}<0.05$, multiple regressions were calculated. Five multiple regressions showing a significant coefficient of determination $\left(R^{2}\right)$ for the multiple correlation $(R)$ are shown in Table 3. 
Table 3. Multiple regression between the fruit quality characteristics and the climatic parameters in the joint investigation from 1981 to 1983.

\begin{tabular}{ccc}
\hline & Combination of highly significant muliple regression coefficients \\
\hline $\begin{array}{c}\text { Multiple } \\
\text { regression } \\
\text { coefficient } \\
(\mathrm{R})\end{array}$ & $\begin{array}{c}\text { Ratio of } \\
\text { contribution } \\
\left(\mathrm{R}^{2}\right)\end{array}$ & Multiple regression equation \\
\hline $\begin{array}{c}\text { Hassaku } \\
0.537^{* y}\end{array}$ & 0.288 & $Y_{6}^{z}=0.8729+9.858 \times 10^{-3} X_{1}+9.301 \times 10^{-3} X_{3}$ \\
'Miyauchi' Iyo & 0.557 & $Y_{6}=0.3507+0.01469 X_{1}-3.503 \times 10^{-5} X_{2}+0.03278 X_{3}$ \\
$0.746^{*}$ & 0.761 & $Y_{4}=582.7-1.515 \times 10^{-4} X_{10}-2.443 \times 10^{-4} X_{11}$ \\
'Washington' and 'Morita' navel orange \\
$\begin{array}{l}0.872^{*} \\
0.877^{*}\end{array}$ & 0.769 & $Y_{5}=10.60+3.726 \times 10^{-4} X_{4}-1.784 \times 10^{-3} X_{5}$ \\
'Marsh' and 'Duncan' grapefruit & \\
$0.996^{* *}$ & 0.992 & $Y_{7}=-131.8+17.41 X_{1}-0.03905 X_{2}+0.7906 X_{3}$ \\
\hline
\end{tabular}

$z \quad Y$ and $X$ are the same as in Table 2 .

y Significant at $\mathrm{P}<0.01\left(^{* *}\right)$ or $<0.05\left(^{*}\right)$.

Table 4. Climatic conditions assocated with high fruit quality in 8 citrus species and cultivars (Results obtained in regression lines shown in Fig. 2-4.).

(1) Hassaku

\begin{tabular}{|c|c|c|c|c|c|c|}
\hline \multirow[b]{2}{*}{ Characteristics } & \multirow{2}{*}{$\begin{array}{l}\text { Desirable } \\
\text { range of } \\
\text { value }\end{array}$} & \multirow{2}{*}{$\begin{array}{l}\text { Mean temp. } \\
\text { from Apr. } \\
\text { to Nov. }\end{array}$} & \multirow{2}{*}{$\begin{array}{l}\text { Annual } \\
\text { effective } \\
\text { cumulative } \\
\text { temp. }\end{array}$} & \multicolumn{2}{|c|}{ Mean diurnal temp. range } & \multirow{2}{*}{$\begin{array}{l}\text { Precipitation } \\
\text { from Apr. } \\
\text { to Nov. }\end{array}$} \\
\hline & & & & $\begin{array}{l}\text { From Apr. } \\
\text { to May }\end{array}$ & $\begin{array}{l}\text { From June } \\
\text { to Aug. }\end{array}$ & \\
\hline Brix & $10^{\circ}-z$ & & & $-9^{\circ} \mathrm{C}$ & $-8^{\circ} \mathrm{C}$ & \\
\hline Citric acid & $\mathrm{y}-1.4 \%$ & & $2,500-2,800^{\circ} \mathrm{C}^{* \mathrm{x}}$ & & & $-1,500 \mathrm{~mm}$ \\
\hline Brix/acidity ratio & $7-$ & & & & & \\
\hline
\end{tabular}

(2) Iyo

\begin{tabular}{llll}
\hline \hline Characteristics & $\begin{array}{l}\text { Desirable } \\
\text { range of } \\
\text { value }\end{array}$ & $\begin{array}{l}\text { Mean temp. } \\
\text { from Apr. } \\
\text { to Nov. }\end{array}$ & $\begin{array}{l}\text { Annual effective } \\
\text { cumulative temp. }\end{array}$ \\
\hline Citric acid & $-1.5 \%$ & $20.5-21.5^{\circ} \mathrm{C}$ & $2.500-2.800^{\circ} \mathrm{C}$ \\
Juice pH & $3.5-$ & $20.5-21.5$ & $2.500-2.800$ \\
Rind thickness & $-7 \mathrm{~mm}$ & $21-21.5$ & \\
Flesh percentage & $60 \%-$ & $20-$ & \\
& $65 \%-$ & $21-22$ & \\
\hline
\end{tabular}

(3) 'Miyauchi' Iyo

\begin{tabular}{|c|c|c|c|c|c|c|}
\hline \multirow[b]{2}{*}{ Characteristics } & \multirow{2}{*}{$\begin{array}{l}\text { Desirable } \\
\text { range of } \\
\text { value }\end{array}$} & \multicolumn{2}{|c|}{ Mean temp. } & \multirow{2}{*}{$\begin{array}{l}\text { Annual } \\
\text { effective } \\
\text { cumulative } \\
\text { temp. }\end{array}$} & \multicolumn{2}{|c|}{ Precipitation } \\
\hline & & Annual & $\begin{array}{l}\text { From Apr. } \\
\text { to Nov. }\end{array}$ & & $\begin{array}{l}\text { From Apr. } \\
\text { to Nov. }\end{array}$ & $\begin{array}{l}\text { From Sept. } \\
\text { to Nov. }\end{array}$ \\
\hline Citric acid & $-1.5 \%$ & & & & $1.200-1.500 \mathrm{r}$ & \\
\hline Juice $\mathrm{pH}$ & $3.6-$ & & $20-21.5^{\circ} \mathrm{C}$ & & & \\
\hline Rind color & $8-$ & & & & & $-600 \mathrm{~mm}$ \\
\hline Shape index of fruit & $1.2-$ & $17-$ & $21^{\circ} \mathrm{C}-$ & $2.700^{\circ} \mathrm{C}-$ & & -600 \\
\hline
\end{tabular}

In 9 major species and cultivars, the climatic parameters of the growing area associated with the fruit quality characteristics are shown in Table 4 . For example, in Iyo, fruits with high quality characteristics, which are associated with a citric acid content of $1.5 \%$ or below, juice $\mathrm{pH}$ of 3.5 and above, rind thickness of $7 \mathrm{~mm}$ and below and flesh percentage of $60 \sim 65 \%$, shoud be produced in a growing area where the mean 
(4) Washington' and 'Morita' navel orange

\begin{tabular}{|c|c|c|c|c|c|c|c|}
\hline \multirow[b]{2}{*}{ Characteristics } & \multirow{2}{*}{$\begin{array}{l}\text { Desirable } \\
\text { range of } \\
\text { value }\end{array}$} & \multirow{2}{*}{$\begin{array}{l}\text { Annual } \\
\text { mean temp. }\end{array}$} & \multirow{2}{*}{$\begin{array}{l}\text { Annual } \\
\text { effective } \\
\text { cumulative } \\
\text { temp. }\end{array}$} & \multirow{2}{*}{$\begin{array}{l}\text { Prepicitation } \\
\text { from Apr. } \\
\text { to Nov. }\end{array}$} & \multirow{2}{*}{$\begin{array}{l}\text { Duration of } \\
\text { sunshine } \\
\text { from Apr. } \\
\text { to Nov. }\end{array}$} & \multicolumn{2}{|c|}{ Amount of solar radiation } \\
\hline & & & & & & Annual & $\begin{array}{l}\text { From Apr. } \\
\text { to Nov. }\end{array}$ \\
\hline \multirow{2}{*}{ Brix } & $11^{\circ}-$ & $16^{\circ} \mathrm{C}-$ & $2,600^{\circ} \mathrm{C}-$ & \multirow{2}{*}{\multicolumn{2}{|c|}{$\begin{array}{l}\text { (Their results were obtained } \\
\text { in 'Suzuki' navel orange) }\end{array}$}} & & \\
\hline & $12^{\circ}-$ & $16.5^{\circ} \mathrm{C}-$ & $2,700^{\circ} \mathrm{C}-$ & & & & \\
\hline Citric acid & $-1.5 \%$ & & & $-1,600 \mathrm{~mm}$ & & & \\
\hline Fruit weigt & $200 \mathrm{~g}-$ & & & & $-1,700 \mathrm{~h}$ & $\begin{array}{l}\mathrm{kcal} / \mathrm{m}^{2} \\
11 \times 10^{5}\end{array}$ & 850,000 \\
\hline Rind color & $8-$ & & & $\begin{array}{l}-1,800 \\
(\text { Annual } \\
-2,200)\end{array}$ & & & \\
\hline Shape index of fruit & -1.02 & & & & $1,400-$ & & \\
\hline Flesh percentage & $78-82 \%$ & & & & & $\begin{array}{l}11 \times 10^{5} \\
-13 \times 10^{5}\end{array}$ & \\
\hline
\end{tabular}

(5) 'Marsh' and 'Duncan' grapef ruit

\begin{tabular}{|c|c|c|c|c|}
\hline \multirow{2}{*}{ Characteristics } & \multirow{2}{*}{$\begin{array}{l}\text { Desirable } \\
\text { range of } \\
\text { value }\end{array}$} & \multicolumn{2}{|c|}{ Mean temp. } & \multirow{2}{*}{$\begin{array}{l}\text { Annual effective } \\
\text { cumulative temp. }\end{array}$} \\
\hline & & Annual & $\begin{array}{l}\text { From Apr. } \\
\text { to Nov. }\end{array}$ & \\
\hline \multirow{2}{*}{ Citric acid } & $-2.2 \%$ & $16.5^{\circ} \mathrm{C}-$ & & $2,600^{\circ} \mathrm{C}-$ \\
\hline & $-2.1 \%$ & $18^{\circ} \mathrm{C}-$ & & $3,000^{\circ} \mathrm{C}-$ \\
\hline Fruit weight & $300 \mathrm{~g}-$ & $17^{\circ} \mathrm{C}-$ & $21^{\circ} \mathrm{C}-$ & \\
\hline Flesh percentage & $70 \%-$ & & $21^{\circ} \mathrm{C}-$ & $2,600^{\circ} \mathrm{C}-$ \\
\hline
\end{tabular}

(6) Ponkan

\begin{tabular}{|c|c|c|c|c|}
\hline \multirow[b]{2}{*}{ Characteristics } & \multirow{2}{*}{$\begin{array}{l}\text { Desirable } \\
\text { range of } \\
\text { value }\end{array}$} & \multirow{2}{*}{$\begin{array}{l}\text { Precipitation } \\
\text { from Apr. } \\
\text { to Nov. }\end{array}$} & \multicolumn{2}{|c|}{ Mean diurnal temp. range } \\
\hline & & & $\begin{array}{l}\text { From Apr. } \\
\text { to May }\end{array}$ & $\begin{array}{l}\text { From Sept. } \\
\text { to Nov. }\end{array}$ \\
\hline Citric acid & $-1.0 \%$ & $\begin{array}{l}1,500 \mathrm{~mm}- \\
-1,300 \\
1,400-\end{array}$ & $-10.5^{\circ} \mathrm{C}$ & $-10^{\circ} \mathrm{C}$ \\
\hline Brix/acidity ratio & $15-$ & $\begin{array}{l}-1,200 \\
1,600-\end{array}$ & & \\
\hline
\end{tabular}

(7) 'Seminole' tangelo

\begin{tabular}{|c|c|c|c|c|c|c|}
\hline \multirow{2}{*}{ Characteristics } & \multirow{2}{*}{$\begin{array}{l}\text { Desirable } \\
\text { range of } \\
\text { value }\end{array}$} & \multicolumn{4}{|c|}{ Mean temp. } & \multirow{2}{*}{$\begin{array}{l}\text { Annual effective } \\
\text { cumulative } \\
\text { temp. }\end{array}$} \\
\hline & & Annual & $\begin{array}{l}\text { From Apr. } \\
\text { to Nov. }\end{array}$ & $\begin{array}{l}\text { From Apr. } \\
\text { to May }\end{array}$ & $\begin{array}{l}\text { From Sept. } \\
\text { to Nov. }\end{array}$ & \\
\hline Citric acid & $-1.5 \%$ & & & & $18.5^{\circ} \mathrm{C}-$ & \\
\hline Brix/acidity ratio & $7-$ & $16.5^{\circ} \mathrm{C}-$ & $20.5^{\circ} \mathrm{C}-$ & $17.5^{\circ} \mathrm{C}-$ & & $2,600^{\circ} \mathrm{C}-$ \\
\hline
\end{tabular}

temperature from Apr. to Nov. ranges from $20^{\circ} \mathrm{C}$ to $21.5^{\circ} \mathrm{C}$ and the annual effective cumulative temperature from 2,500 to $2,800^{\circ} \mathrm{C}$.

Multiple regressions were obtained between the shape index of fruit of Hassaku and 'Miyauchi' Iyo, the fruit weight and rind color of navel oranges and the flesh percentage of grapefruit, and 2-3 climatic parameters. For example, the value of $79.24 \%$ for the flesh percentage of grapefruit corresponded to $17^{\circ} \mathrm{C}$ for the annual mean temperature $\left(X_{1}\right)$, $2,699^{\circ} \mathrm{C}$ for the annual effective cumulative temperature $\left(X_{2}\right)$ and $21^{\circ} \mathrm{C}$ for the mean temperature from Apr. to Nov., respectively. Multiple regressions which were obtained for morphological characteristics of fruit could not be obtained for inherent fruit quality.

The correlations and single and multiple regression equations for monthly mean temperature, monthly duration of sunshine and monthly amount of solar radiation were calculated from the data obtained in the joint investigations from 1981 to 1983, and are shown in Table 5 . 
Table 5. Relationships among monthly amonut of solar radiation, monthly mean temperature and monthly duration of sunshine in the meteorological data surveyed in 1981-83.

1. Single regression

\begin{tabular}{ccccc}
\hline $\begin{array}{c}\text { Location } \\
\text { or } \\
\text { Month }\end{array}$ & $\begin{array}{c}\text { Dependent } \\
\text { variable }\end{array}$ & $\begin{array}{c}\text { Independent } \\
\text { variable }\end{array}$ & $\begin{array}{c}\text { Combination of highly significant correlations } \\
\text { coefficient } \\
(\mathrm{r})\end{array}$ & Regression equation \\
\hline
\end{tabular}

(1) On all data in the 7 locations for 3 years

$\begin{array}{llll}Y^{\mathrm{z}} & X_{1}{ }^{\mathrm{y}} & 0.604^{* * \mathrm{x}} & Y=55552.9+2257.73 X_{1} \\ Y & X_{2} & 0.580^{* *} & Y=29736.8+367.42 X_{2}\end{array}$

(2) On all data from Apr. to Nov. in the 7 locations for 3 years

$\begin{array}{llll}Y & X_{1} & 0.444^{* *} & Y=48770.6+2562.42 X_{1} \\ Y & X_{2} & 0.638^{* *} & Y=39900.8+352.398 X_{2}\end{array}$

(3) On data in each location for 3years

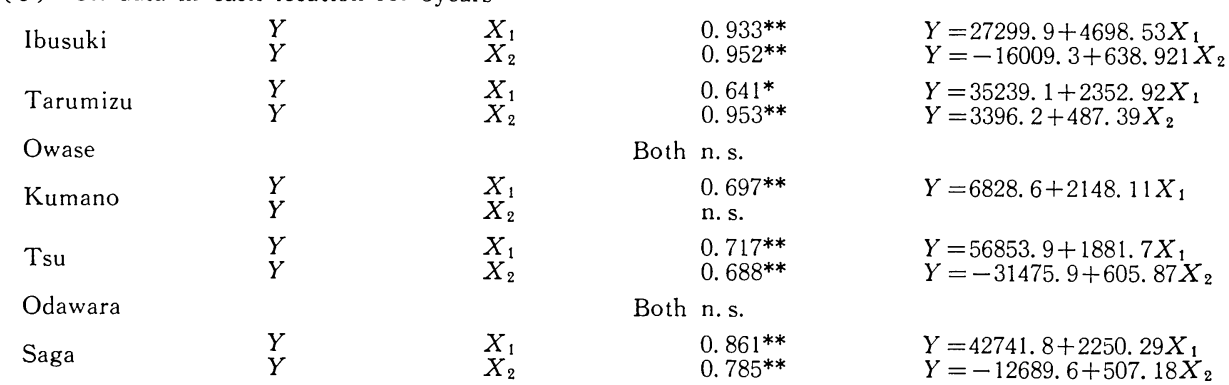

(4) On monthly data in the 7 locations for 3 years

\begin{tabular}{|c|c|c|c|c|c|}
\hline Jan. & $\begin{array}{l}Y \\
Y\end{array}$ & $\begin{array}{l}X_{1} \\
X_{2}\end{array}$ & & $\begin{array}{l}\text { n. s. } \\
0.721^{*}\end{array}$ & $Y=-7009.9+450.61 X_{2}$ \\
\hline Feb. & $\begin{array}{l}Y \\
Y\end{array}$ & $\begin{array}{l}X_{1} \\
X_{2}\end{array}$ & & $\begin{array}{l}\text { n. s. } \\
0.808^{* *}\end{array}$ & $Y=19847.9+347.62 X_{2}$ \\
\hline March & & & Both & n. s. & \\
\hline Apr. & & & Both & n.s. & \\
\hline May & & & Both & n. s. & \\
\hline June & & & Both & n.s. & \\
\hline July & $\begin{array}{l}Y \\
Y\end{array}$ & $\begin{array}{l}X_{1} \\
X_{2}\end{array}$ & & $\begin{array}{l}0.771^{*} \\
0.762^{*}\end{array}$ & $\begin{array}{l}Y=-171232+11184.7 X_{1} \\
Y=63739.2+295.33 X_{2}\end{array}$ \\
\hline Aug. & $\begin{array}{l}Y \\
Y\end{array}$ & $\begin{array}{l}X_{1} \\
X_{2}\end{array}$ & & $\begin{array}{l}0.649^{*} \\
\text { n. s. }\end{array}$ & $Y=-255569+13860.0 X_{1}$ \\
\hline Sept. & & & Both & n. s. & \\
\hline Oct. & $\begin{array}{l}Y \\
Y\end{array}$ & $\begin{array}{l}X_{1} \\
X_{2}\end{array}$ & & $\begin{array}{l}\text { n.s. } \\
0.671^{*}\end{array}$ & $Y=24370.4+344.847 X_{2}$ \\
\hline Nov. & & & Both & n. s. & \\
\hline Dec. & $\begin{array}{l}Y \\
Y\end{array}$ & $\begin{array}{l}X_{1} \\
X_{2}\end{array}$ & & $\begin{array}{l}0.641^{*} \\
\text { n.s. }\end{array}$ & $Y=34882.5+3328.99 X_{1}$ \\
\hline
\end{tabular}

In the yearly data, the monthly data from Apr. to Nov. at the 7 locations, there were a number of multiple significant correlation coefficients and significant multiple regression coefficients among the 3 elements, except for Odawara and the month of March, Apr., May, Aug., Spet. and Nov. This finding suggests that it is possible to regress the amount of solar radiation by the mean temperature or the duration of sunshine.

\section{Discussion}

Adaptability of citrus species and cultivars, should be reflected in high yield with annual bearing and distinctive quality of the fruit at a low cost. Most of the citrus species have been selected from subtropical regions. The growth habit and fruit quality characteristics of citrus are highly sensitive to light and temperature within a given environment, and the response to each factor varies with the citrus species and cultivar. 
2. Multiple regression

(Table 5. Continued from former page)

\begin{tabular}{|c|c|c|c|}
\hline \multirow[b]{2}{*}{$\begin{array}{c}\text { Location } \\
\text { or } \\
\text { Month }\end{array}$} & \multicolumn{3}{|c|}{ Combination of highly significant multiple regression coefficients } \\
\hline & $\begin{array}{l}\text { Multiple } \\
\text { regression } \\
\text { coefficient } \\
(\mathrm{R})\end{array}$ & $\begin{array}{l}\text { Ratio of } \\
\text { contribution } \\
\qquad\left(\mathrm{R}^{2}\right)\end{array}$ & Multiple regression equation \\
\hline \multicolumn{4}{|c|}{ (1) On all data in the 7 locations for 3 years } \\
\hline & $0.721^{* * x}$ & 0.521 & $Y=9060.3+1768.43 X_{1}+314.79 X_{2}$ \\
\hline \multicolumn{4}{|c|}{ (2) On all data from Apr. to Nov. in the 7 locations for 3 years } \\
\hline & $0.699 * *$ & 0.489 & $Y=9642.24+1817.34 X_{1}+312.87 X_{2}$ \\
\hline \multicolumn{4}{|c|}{ (3) On data in each location for 3 years } \\
\hline Ibusuki & $0.987^{* *}$ & 0.968 & $Y=-6529.96+2320.23 X_{1}+382.773 X_{2}$ \\
\hline Tarumizu & $0.941^{* *}$ & 0.886 & $Y=3917.30-171.080 X_{1}+504.048 X_{2}$ \\
\hline Owase & $0.780^{* *}$ & 0.609 & $Y=-16438.3+2709.73 X_{1}+451.123 X_{2}$ \\
\hline Kumano & $0.779^{* *}$ & 0.626 & $Y=-1450.45+2723.21 X_{1}+355.379 X_{2}$ \\
\hline Tsu & $0.791^{* *}$ & 0.626 & $Y=-14040.1+1360.08 X_{1}+412.741 X_{2}$ \\
\hline Odawara & n.s. & & \\
\hline Saga & $0.883^{* *}$ & 0.779 & $Y=9648.77+1589.07 X_{1}+243.13 X_{2}$ \\
\hline \multicolumn{4}{|c|}{ (4) On monthly data in the 7 locations for 3 years } \\
\hline Jan. & $0.841^{* *}$ & 0.707 & $Y=-2758.8+3020.21 X_{1}+462.081 X_{2}$ \\
\hline Feb. & $0.814^{* *}$ & 0.662 & $Y=6396.45+1749.57 X_{1}+362.017 X_{2}$ \\
\hline March & n.s. & & \\
\hline Apr. & n.s. & & \\
\hline May & n.s. & & \\
\hline June & $0.647^{*}$ & 0.418 & $Y=219091-7068.22 X_{1}+277.638 X_{2}$ \\
\hline July & $0.726^{*}$ & 0.527 & $Y=-77729.1+6493.81 X_{1}+152.523 X_{2}$ \\
\hline Aug. & n.s. & & \\
\hline Sept. & n.s. & & \\
\hline Oct. & $0.672^{*}$ & 0.451 & $Y=-22918.8+2527.77 X_{1}+343.343 X_{2}$ \\
\hline Nov. & n.s. & & \\
\hline Dec. & $0.784^{*}$ & 0.614 & $Y=-16172.1+4207.19 X_{1}+256.907 X_{2}$ \\
\hline
\end{tabular}

z $Y$; Monthly amount of solar radiation $\left(\mathrm{kcal} / \mathrm{m}^{2}\right)$

y $X_{1}$; Monthly mean temperature $\left({ }^{\circ} \mathrm{C}\right)$

$X_{2}$; Monthly duration of sushine (h)

$\times$ Significant at $\mathrm{P}<0.01\left(^{(*)}\right)$ or $<0.05\left(^{*}\right)$

n. s.; Abbreviation for non significance

In this study, correlations and single and multiple regressions between the fruit quality characteristics of major citrus species and cultivars and the climatic parameters in the citrus growing areas were analyzed.

In relation to the climatic adaptability of trees in the citrus growing areas, Nakagawa (4) investigated the climatic conditions of citrus growing areas in Japan and overseas and determined the suitable effective cumulative temperature and extremes of low temperature and frequency in the growing area of satsuma mandarin for storage, 'Natsudaidai', Ponkan, 'Washington' navel orange, 'Valencia' orange, lemon and grapefruit. He also suggested that the daily mean temperature should be taken as a basis when the effective temperature affecting the growth of the tree and the development and maturation of fruit are determined. In the current study the same method was adapted.

Temperature is the climatic factor that most affects fruit quality characteristics. Several authors $(3,5,9)$ have analyzed the effect of temperature upon each of the quality characteristics and the maturation of fruit on tree, using several methods including the sum of degrees per day. The relationships between fruit quality characteristics and factors relating to temperature which were observed in our surveys showed a similar tendency. The fruit quality characteristics which were particularly affected included citric acid content, Brix/acidity ratio, juice $\mathrm{pH}$, 
rind thickness, flesh percentage, shape index of fruit and fruit weight. Among the temperature parameters the most important ones were the annual mean temperature, mean temperature from Apr. to Nov. and annual effective cumulative temperature.

Sanchez Garcia and Fernandes (8) stated that in the tropical climate of Cuba, temperature and rainfall during the two months preceding harvest affected the peel thickness, fruit shape, total soluble solid, soluble solid/ acid ratio and acidity, which should be considered as basic characteristics in determining the fruit quality. Rainfall was observed to have the most significant effect on the first 2 characteristics, while temperature had the most effect on the last 3 characteristics.

This report showed contradictory results in the relationships between the precipitation from Apr. to Nov. and the citric acid content of Ponkan fruit(Table 4(6)). Such disagreement could be ascribed to the interaction of factors including the development and maturation period of fruit.

Reuther et al(6) studied 'Valencia' orange in four different climatic acreas in the USA and found differences in peel thickness that were related to the prevailing temperature and humidity conditions in each region. In our study these findings only agree with the results obtained in Iyo.

As expected, the maturity index of the fruit, was correlated with the Brix values and citric acid content in juice. Changes observed in the fruit quality characteristics related to the climatic parameters did not correspond to the variations in the Brix values but correspond to the variations in the citric acid content and the Brix/acidity ratio.

The variations in fruit quality characteristics which were found to be associated with the temperature could be more significantly correlated with the effective cumulative radiation controlling the total photosynthetic rate of the citrus trees. In this report, the fruit weight of navel orange only showed a significant regression with the amount of solar radiation.

Except for some locations and a few months the relationships between mean monthly temperature, monthly duration of sunshine and monthly solar radiation were highly significant. The annual cumulative amount of solar radiation should be determined in similar and future investigations to assess the adaptability of citrus species.

\section{Acknowledgment}

The authors wish to thank the members of the Citrus Experiment Station of each prefecture for providing the data on the climatic parameters and the fruit quality characteristics throughout this work.

\section{Literature Cited}

1. COOper, W. C., A. Paynado, J. R. FurR, R. H. Hilgeman, G. A. CaHoon and S. B. Boswell. 1963. Tree growth and fruit quality of 'Valencia' oranges in relation to climate. Proc. Amer. Soc. Hort. Sci. 82 : 180-192.

2. FUCIK, J. E. and J. NORWINE. 1979. Climatological parameters and grapefruit size relationships in the Rio Grande Valley of Texas. J. Rio Grande Valley Hort. Soc. $33: 4-6$.

3. JONES, W. W. and C. B. CREE. 1965. Environmental factors related to fruiting of 'Washington' navel oranges over a 38 year period. Proc. Amer. Soc. Hort. Sci. $86: 267-$ 271.

4. NAKAGAWA, Y. 1969. Studies on the favorable climatic environments for fruit tree culture. VI. Analysis of climatological condition in the major citrus production area in the world. Bull. Hort. Res. Sta., Japan Ser. A No. 8.: 73-94. (In Japanese)

5. ReUTHER, W. 1975. Climate and citrus behavior. The citrus industry $3: 280-337$.

6. Reuther, W., G. K. RASMUSSEN, R. H. HilgeMAN, G. A. CAHOON and W. C. COOPER. 1969. A comparison of maturation and composition of 'Valencia' oranges in some major subtropical zones of the United States. J. Amer. Soc. Hort. Sci. $94: 144-157$.

7. Reuther, W. and D. Rios CASTANOS. 1969. Comparison of growth, maturation and composition of citrus fruits in subtropical California and tropical Columbia. Proc. 1 st Int. Citrus Symp. I.: 277-300.

8. SANCheZ Garcia, C. D. and M. A. Fernandes. 1981. Climatic effects on 'Valencia' oranges in eastern Cuba. Proc. 3 nd Int. Soc. Citriculture. I.: $331-334$.

9. UTSUNOMIYA, N., H. YAMADA, I. KATAOKA and T. TOMANA. 1982. The effect of fruit temper- 
ature on the maturation of satsuma mandarin (C. unshiu Marc.) fruits. J. Japan. Soc.
Hort. Sci. 51:135-141. (In Japanese with English summary)

気象要素と果実品質変動の関係とカンキツの適地性について

\author{
岩崎 直人・大垣 智昭 \\ 筑波大学農林学系 305 茨城県桜村 \\ 岩 政 正 男 \\ 佐賀大学農学部 840 佐賀市本庄町 \\ 松島二良 \\ 三重大学農学部 514 津市上浜町 \\ 石 畑 清 武 \\ 鹿児島大学農学部 890 鹿児島市郡元
}

\begin{abstract}
摘 要
わが国のカンキツ生産各地における気象要素, すなわ ち温度, 降水量, 日照, 日射と主要な中晚生カンキッの 果実品質値とを調査もしくは収集し，その間の回㷌並び に重回帰解析を行らことによって，良好な品質の果実生: 産地の気象要素の範囲を知ろらとした.

温度は果実品質変異に最も影響するが，なかでもクエ 栖夋含量, 甘味比, 果汁 $\mathrm{pH}$, 果皮厚, 果肉率, 果形指 数, 果重が变異し, 温度に関する測定項目としては, 年 及び $4 \sim 11$ 月の平均温度, 有効積算温度の影響が強い.

雨もまた，果実品質に有意な影響を与えることを見出 したが，とくにクェン酸に，果実発育，成熟の時期别の

果実品質中, 果汁のBrix はクエン酸や甘味比注ど気 象要素に感応しない。

各果実品質項目を従属变数として冬気象要素を独立变 数とする重回帰は 5 式得られた。また, 得られた単回帰 式と重回㷌式から，良好な品質の各中晚生カンキッ果実 の得られる気象要素の範囲を提示した。

4 大学連絡調査結果 $(1981 \sim 1983)$ から, 月平均温度, 月日照時数及び月日射量との間に高い相関があり, 回㷌 関係が成立する. 光合成能と日射量との関係から考え て, 有効積算温度と同様に有効積算日射量による適地判 定が考慮されなければならない。
\end{abstract} 降水強度によって相矛盾した結果が現れる。 